\title{
Contextual Interpretation of Quaid-e-Azam Muhammad Ali Jinnah's Concept of Islam
}

\author{
HajraSalim
}

Ph.D Research Scholar

Department of History\& Pakistan Studies

The Women University, Multan

\section{Abdul Rashid Khan}

Professor

Department of History

Bahauddin Zakariya University, Multan

\begin{abstract}
Quaid-e-Azam Muhammad Ali Jinnah was the most controversial, misinterpreted and misunderstood personality in the South Asian history of Freedom Movement. Not only Indian and British historians but also Pakistanis historians are confused about his sect and beliefs. Jinnah's figure was buried under the layers of propaganda. This is the most contentious discussed issue in Pakistan among the different scholars. Both right and left wing intellectuals sought legitimacy of their views with the vision of Jinnah, either the Jinnah was secular or Islamist. The object of the purposed research paper is to analyze and understand the Religious Concept of Quaid-e-Azam Muhammad Ali Jinnah and also explore his concept of Islam to resolve the problematic condition of the nature of Pakistani state. Contextual interpretation of Struggle Movement has great importance for analyzing the character and active participation of our great leader and also necessary for removing the misunderstandings about his personality. Different historians, intellectuals, scholars and thinkers are doing their best to prove him a secular or Islamist leader according to their own point of view and perception with the references of his speeches, statements, different events of his life and from his works. His personality was interpreted by the historians from different angles and aspects to clear the questions that were raised in their minds about his secularism.
\end{abstract}

\section{Introduction:}

In this most modern discourse, both secularists and Islamists scholarshave their ownpoint of view about Quiad-e-Azam's personality. The first group gives arguments on Shar'ha based upon his views about Islamic state and they prove him as an Islamistwho believed and followed the principles of Islam with providing the references from his speeches,statements and events of his daily life. On the other hand, the circle or lobby of left wing intellectuals maintains that the nature of state should be secular, modern democratic and progressive according to Jinnah's mindset. They also think that Jinnah actually adopt a secular approach towards Pakistan as dealing legal and constitutional problems that can be clearly derived from his speeches and statements. They believed that Jinnah played an 
emotional Islamic card for the political exigencies to achieve the favour of Indian Muslims. Scholars who subscribed to the secularist view, they take their arguments with reference to Quaid's speech of $11^{\text {th }}$ August 1947, in Legislative Assembly and quote examples from his life era before 1937 to prove him secular leader. These scholars have always used couple of lines from this speech and misinterpreted it that Quaid wanted a secular Pakistan where religion would have nothing to do with the state. These lines are"You are free; you are free to go to your temples, you are free to go to your mosques or to any other place of worship in this State of Pakistan. You may belong to any religion or caste or creed that has nothing to do with the business of the State". 1

$11^{\text {th }}$ August 1947 was the date from which the creation of Pakistan was for from the distance of three days. Millions of peoples moved from India to Pakistan. These Migrants faced horrendous slaughter for the quest of new homeland from Hindus and Sikhs mobs. At that time, Jinnah was determined that no such slaughter of minorities should took place in Pakistan. That was the time of challenges, which faced by the newly formed Pakistan from the Indians and from the minorities of Pakistan, which were misguided by the Anti Muslim and Anti Pakistan lobbies. Minorities were nervous in this condition and wanted to migrate to India. Jinnah wanted to remove the fear and panic from the Non-Muslims livings. This speech of $11^{\text {th }}$ August 1947 is often quote repeatedly interpreted and often misinterpreted by speakers and writers. Some of them are of the view that Jinnah had bid farewell to his TwoNation Theory. There are many instances to establish the fact that Jinnah posited politics and religion in two separate compartments. At that time, Jinnah's responded through his speeches of $11^{\text {th }}$ August 1947 and $14^{\text {th }}$ August 1947, both speeches related with each other, and the continuation of same thoughts process. As a Governor General of Pakistan, Jinnah's thinking was turning into humble. Struggle Movement was succeeded, many eminent opponents and other people during the Struggle Movement asked about Pakistan. His answer was mostly that a free life on democracy pattern in Pakistan and ideology of Islam.Not only have that, to justify their arguments some scholars often distorted the truth about Quaid's life and his work.

Authors of the category of left wing mostly use Marxist frames to illustrate and analyzestruggle movement like HamzaAlvi, Dr Mubarak Ali, HadirJavid Syed, Khalid Ahmad, Khan Abdul Wali Khan, Aisha Jalal, A.Rehman, Dr Hassan Askri, ImtiazAlam, Rashid Rehman, Justice Munir ,RahatSaad-ul-Khairi and Pro RiazSaddiqui,theyal belong to 
left wing intellectuals. These eminent scholars described Jinnah as an avowedly secular leader. They dub Jinnah as a secularist, separatist, egoist, responsible of bloodshed during partition and worked as a British agent. Dr. Mubarak Ali said about him "Jinnah used to be a perfect secularist as far as his private life was concerned, yet he believed in using religion for public consumption to achieve his political ends. The propelling slogan during the struggle for Pakistan was to establish a distinct identity of Muslims as a nation. Jinnah used Islam as a motivating force to get trust of the Muslims to the cause of Pakistan politically. But, the state, they aimed to create was to be secular, not a theocratic. "2 This is right he had a secular approach in beginning of his political career but with the passage of time, his thinking was developed and changed according to Islam as a true Muslim. HazratJamat Ali Shah was a famous personality of Indo-Pak. He performed 60 pilgrims in 110 years of his age. He said that Quaid was a Waliuallah' and the building of Pakistan was passed by the Allah Almighty. He said that someone says about respected Quaid, "he is a non-Muslim" someone says him Murtid. Whenever somebody says about Quaid that he belonged to Shi'a sect but I say that he is man of Allah. People have their own view but I say in the light of Quran and Hades. Lesson and ALLAH says in the Holy Quran, the people when brought faith and then perform good deeds, God provokes love in the heart of people for then Now you tell me is there, any person who is the hero among all of you and the ten Billion Muslim of sub-content has keep love for him like a Quad-e-Azam, so it is the decision of Quran. Now, remained the subject as according to my prohibition, oho, oppose or rivals you can say him a Non-Muslim but I says he is the Wail ALLAH. ${ }^{3}$ It is fact that the overwhelming majority believed that our Quaid was a true Muslim in true spirit of truthfulness and bore strong character which could not be degraded by his opponents.

Although Jinnah could not accepted religious slogan raised by Muslim League workers but gradually, he accepted this slogan with whole heartily. If he did notbelieve on that slogan then he must denied it and ordered them to stopped it during Muslim League campaign. But he could not do this. Jinnah increasingly talked about a Muslim identity, yet he would emphasized on Islamic tolerance. Pakistan itself would be based on the high principle laid down by the Prophet (PBUH) in Arabia in the $7^{\text {th }}$ Century. Although Jinnah had pointed out the flaws in Western style democracy, it was still the best system of government available in Muslims. Jinnah unequivocally did not want a theocratic state run by Mullahs. There are many written pieces of work by Quaid-e-Azam in which he referred the different 
aspects, acts and ingredients of Islam as should be bases and cru for the constitution and state of Pakistan. We must adopt the knowledge about Quran and Sunnah, kalma, Islamic way of life, Muslim culture, Islamic tradition, Islamic ideas, Islamic way of ruling the state and Muslim unity for the basis of Pakistan.

Another intellectual is A. Rehman who was a Director Human Rights Commission of Pakistan and former editor of daily "The Pakistan Times" illustrates his personality as "Jinnah was a secularist given the fact that he always adopted a secular approach while dealing with constitutional and legal issues." ${ }^{4}$ When Pakistan came into being, there were a large number of Non-Muslims were stayed here. Pakistan achieved on the basis of the power of pen not on the power of weapons. It had no much weapons for war. We could not compete enemieswithout weapons and that was understood by jinnha, so he gave importance only the protection of Muslim religion, culture and values. If he could not talked about equal citizenship at that time then we had to fight not only externalpowers but also internal communities. Charter of Madina is the best example of the safety of Islam which was also practised by Jinnah according to the circumstances. Islam is such type of beautiful religion who convertHaram into Halal for saving of one's life. Then why our honourable intellectuals cannot understand these things. All speeches and statements of Jinnah filled with the reference of Islam, Islamic history, Quran and Hdis. Jinnah's understanding about Islam was much better as comparedto any other religious so called Mullas. He was a true Muslim with clear understanding about Islamic soul.

Another prominent person Dr. Hassan AskariRizvi described that "Jinnah definitely was a secularist who viewed Islam as an instrument of identity formation and political mobilization for the Muslims of South Asia. Whenever he talked about Islam, he also talked about the modern notion of the state, constitutionalism, civil and political rights and equal citizenship irrespective of religion or any other consideration." ${ }^{5}$ Quaid had no personal benefits. he did not collect any property for his coming generation. His only aim was the safety and sympathy of Muslims. He had no need to use Islamas an emotional instrument. If we observed his life through childhood then we will know that he was not telling a lie, no body canpurchased him at any cost and he had a strong character which his enemies were also believed. No body raised fingers on his character throughout his whole life from childhood till death. That's why such type of propaganda is useless against him. Jinnah talked about the equal citizenship for the strong foundations of Pakistan. Equality of citizenship in 
Pakistan was the need of the time because that was necessary for the protection of Islam and Muslims in sub continent and Islam allow flexibility for the benefits of people. Rigidity is death and elasticity is life.

ImtiazAlam, Secretary General South Asia Free Media Association said that "Mohammad Ali Jinnah envisioned Pakistan as a modern democratic state to be run strictly on the basis of merit and where all citizens will be equal before the law." ${ }^{6}$ This is right that Jinnah forced on equality and merit but his aim to become a Pakistan an Islamic state on the basis of flexible policies according to the circumstance. That was proved that Jinnah do that who were not done by rigid strict Mullas and that was a miracle in the history. Late Justice Munir writes in his book "there can be no doubt that Jinnah was a secularist" and "the pattern of Government which the Quaid had in mind was a secular democratic government."7 RahatSaad-ul-Khairi while writing his book on Quaid-e-Azam also asserted, "Jinnah never wanted to make Pakistan an Islamic state." ${ }^{8}$ So, they all argue that Quaid's plan was to build this state on a secular, democratic, and liberal structurewhereas Islam principles had no prominent place. About the Islamic aspect in the movement, the left wing scholars are of the view that the slogan of Islam raised during the Pakistan Movement was not the official slogan of Muslim League nor jinnah ever raised it, rather it was being chanted by the workers at the lower level. It was raised just for motivating the Muslim for achievingtheir support while basic end was protection of political, cultural and economic interests of the Muslims of India in a secular State of Pakistan. On the other hand ,The Islamists promoted the arguments that Jinnah was a true Muslim, fought for the security of Muslim rights, create state for the implementation of the principles of Islam and wanted to make it bulwark of Islam. He was conscious and sensitive Muslim who had deep love and awareness about the true spirit of Islam. Scholars like Dr.SafderMahmood, Dr.Riaz Ahmad, Saeed Ahmad, Dr.M.RafiqAfzal, MunshiAbdurRehman, Z.H. Zaidi, Shrif-ul-Mujahid and Z.A. Suleri considered Quaid-e-Azam a saviour of the Muslims, protector of Islam, struggled hard for the independent Islamic country for the Muslims of sub-continent. Z.A Suleri said "Quaid wanted that a democratic Constitution, based on Islamic values, traditions and laws be framed at the earliest." 9

Muhammad Ali Jinnah was belong to Shia sect But he never revealed his hostility towards any sect of the Muslims. He always remained non-sectarian and worked for the cause of whole Muslim community. It is definitely true that Jinnah did not show his affiliation 
towards any sect of Muslims. Nor he verified himself as a theologian personality. Jinnah himself accepted that he was not a learned Maulana or Maulvi. In 1970, Sindh High Court, in its detailed decision said that Mr. Jinnah till last movement of his life was a Muslim who did not belong to any sect. He was the first person in Pakistan to be legally recognized as a Muslim of no sectarian affiliation according to the High Court of Sindh that he was a Muslim of no sect. ${ }^{10} \mathrm{He}$ was only a simple Muslim. AlthoughIn his early phase, Jinnah described himself as a staunch Congressman who had no love for religion or sectarian crises. Jinnah was feared about the war of sectarianism among Muslims. He knew that sectarianism is a disease who destroyed the unity of his people which was most important for achieving the separate country for Muslims. So, that was the reason, he did not use Islam as an instrument because he did not want that Muslims fight with each other because of sectarianism and non Muslim saw their disunity. His first preference was unity of Muslim of India which was only be possible without sectarianism crises. If jinnah did not use his wisdom at that time then Pakistan remained a dream which could not fulfil at any cost by religious groups who were divided in different sects.He worked for the solution of the problems of whole country without discrimination of any community. So, his selfless patriotism and an outstanding political contribution won him honour, popularity and the love of his people. "He was given the titles of the 'Apostle of United India', uncrowned Prince of Bombay', Muslim-Maizini', Zaghhlol Pasha of Indian politics', ambassador of Hindu-Muslim unity', a great hearted Prince of Indian Nationalist', and 'Modern Akbar' ". ${ }^{11}$ Nobody raise finger on his truthfulness, sincerity and good characters. That was the symbol of his true Muslimwho was chosen by Allah for doing a great job in the shape of separate Muslim country Pakistan.

Jinnah's education was started in religious atmosphere. After completing basic and early education, he went to England to acquire business experience. But in London, his mind was changed and he joined Lincoln's Inn for the degree of Law on $5^{\text {th }}$ June 1893 in spite of business. He had joined Lincoln's Inn out of four famous educational institutions because the name of Prophet Muhammad (PBUH) was written on its main entrance. Quaid had a great love for the Holy Prophet (PBUH) and this can be proved on several occasions of his life. He believed that he was a great lawgiver, great political leader, great teacher and a great reformer. He married to his second wife Ruttan on Friday April 19, 1918. She had converted to Islam three days earlier, though she remained a non sectarian mystic in her life." ${ }^{12}$ her Islamic name was Maryam Jinnah. Quaid did not accept her before embracing Islam. The Nikah ceremony of Jinnah was performed by a Shi'aAalim, MolanaHasanNajfi according to 
the Shi'a Twelver sect. In this Nikha, Haji Shekh Abu ulQasimNajfi was elected the advocate of RattenBai and Jinnah elected Muhammad Ali Khan Sahib Muhammoda Abad as his advocate. MohtrmGhulam Ali, Sharif bhaiDewjee and UmerSobaniwas signature on Nikhahnama as a witnesser. ${ }^{13}$ If Quaid had a secular approach then why couldnot accepted RattanBai as a parsi girl and insisted her for adopting Islam. This incident provedhis love and importance for Islam and Islamic values of life. Rattan Bai died in 1929 in Bombay and her Namaze jnazaand last rituals werealso performed according to the Islamic values on the instructions of Jinnah and she was buried in the KhwajaTwelverShi'a graveyard. Jinnah's only child Dina Jinnah married with Parse boy Neville Wadia. He disowned his daughter because she disobey the laws of Islam.

He died at 10:20 P.M. on September 11, 194814. Dr.Riaz Ahmad said, "His last words before death was, ALLAH--------Pakistan. He was buried the next day $12^{\text {th }}$ September, $1948^{15}$ at 6.P.M. with full military honour. ${ }^{16} \mathrm{He}$ had two separate funeral prayers according to Shi'a and Sunni sect. His Ghusal was arranged by a Shi'a scholar Syed AnisulHasnain and also led Quaid's funeral prayer in GovernerGernal's House. At that time, AftabHatimAlaviYousafHaroon, and HashimRaza were present.All these personalities belonged to Shi'a sect. First performed Shi'a rituals and then after that the body of Jinnah was handed over to the nation. MolanaShabir Ahmad Usmani, a Sunni scholar led his funeral in the ground. ${ }^{17} \mathrm{He}$ took his start as a secular leader but after analyzing the facts about Hindus mentality, he started studying Islam andincreased knowledge about Islamic values, Islamic laws and became a true Muslim leader. Now, he changed his priorities and worked for the cause of the perseverance of Islam, its traditions and its culture.He tried to give his aspirations and ideas to a practical shape during his period of $13^{\text {th }}$ months as a Governor General of Pakistan. He advised the people through his speeches to prepare themselves to undertake the task of organizing their cherished ideology in Pakistan. Jinnah retained J.N Mandal as the first Law Minister of Pakistan, this decision made it fully clear that the Quaid did not want politics to be influenced by faith. Finally Quaid won Pakistan with the power of pen through forceful arguments, which he gave to convince British and Hindus for achieving separate Muslims country.

In September 1947, the question was raised that the name of Quaid-e-Azam was included in the khutba of Jummah or not? So a representator of Dawn asked about it from AllamaShabir Ahmad Usmani, President of JameyateUlema-e-Hind and the member of 
Constitution Assembly Pakistan. He said, "That the tradition dated back from the time of Ummayyads. The Abbissids were more particular about inclusion of the name of the Caliphs. According to him the name will automatically come in if the Khutba was properly delivered and the spirit of the institution was maintained. And undoubtedly, the Quaid-e-Azam is the head of the Muslim State of Pakistan," 18 Islam is such type of religion which gave more stress on the building of character and Jinnah stood on the highest peak of character.Address at the Annual convocation of the Islamia College, Lahore on March $24^{\text {th }} 1946$, he said: "stressing the need for a high national character to achieve the desired goal, the test of a man depends upon his standard of morality in every walk of life, his elements, his principles, and very often it is named character. Character means a bundle of virtues, the highest sense of honour and integrity and that you will not sell your principle for anything in the world, however tempting it may be. These are the characteristics which go to make a nation. When a test comes, a crisis comes, if you live up to these virtues, no one on the surface of the earth can defeat you." 19 Speech at Lahore on October $30^{\text {th }} 1947$, he said, "Keep up your morale. Do not be afraid of death. Our religion teaches us to be always prepared for death. We should face it bravely to save the honour of Pakistan and Islam. There is no better salvation for a Muslim than the death of a martyr for a righteous cause." ${ }^{20}$ Jinnah had no fear of death. Like a Moman, He believed that life and death is in the hand of God. So, any hardships on the way of his mission, could not afraid him because he had strong believe on ALLAH's Will. Mountbatten alarmed Quaid-e-Azam about the danger and treachery of Sikh, when he was going to attend the ceremony of $14^{\text {th }}$ August. He even forbade him as not to go there but Quaid's faith and farm belief on Allah cannot stop him to go there and he said, I will go there, I must do there. When he came back, Lord Mount Batten said, Quaid I want to congratulate you from the core of my heart as you came out alive. Probably, because I was sitting with you, Quaid-e-Azam replied, No! My Allah was my benefactor that is why I remained alive. I had firm belief on the greatness of Allah Almighty. Jinnah was a dominating figure in Indian politics because of his unimpeachable public character.

\section{REFLECTIONS OF ISLAM}

when we study deeply the speeches and statements of Jinnah then it becomes clear that he was a man of principlewho had a clear and deep sense of Islam, Islamic laws and Islamic History. He said; "Islam is also a code for every Muslim, which regulates his life and his conduct even in politics and economics and the like. It based on the highest principles of 
honour, integrity, fair play and justice for all. One God and the equality of one God is one of the fundamental principles of Islam. In Islam, there is no difference between man and man. The qualities of equality, liberty and fraternity are the fundamental principles of Islam." ${ }^{21}$ Quaid's concept of Islam was the combination of Islamic and modern values of life. It is in this context, intellectuals were confused about Jinnah's concept of Pakistani state and Islam. He gathered all the Muslims of India under the philosophy of one nation which stand onpure Islamic values and denied sectarianism. Jinnah always remained non-sectarian in his approach to Islam because he knew better that sectarianism is a poison for the state. Quaid's two sisters were married in Sunni families, Qasim Jamal who belonged to a Sunni khwajafamily married with his sister Rehmat Be on the strong will of Jinnah. His second sister Maryam Be also married in a Sunni sect young boy AbdieenPeerbhai and this decision was also taken by Jinnah himself. These were the best examples of his nonsectarianism.Jinnah considered it the main cause of Muslims problems and hardships. So he advised the Muslims to forget the sects and followed the basic teachings of Islam only. In this phase, he appeared as a man of Islamic faith continental thought with English appearances. He wanted and advocated the cause of self-development, self-defence, self-government and self-justice for his countrymen. His struggle was based on Indian's interests in general and the Muslims in particular.

\section{Quaid's Vision of Islam}

Jinnah considered Islam as a perfect religion. He said that every matter of life can be discussed and solved in Islam. He sought guidance from Holy Quran and the teachings of Holy Prophet (PBUH) in his daily life. Our salvation only lies in following the golden rules and principles of Islam. He manifested his opinions on many occasions. He said "Islam gives us a complete code. It is not religious but it contains laws, philosophy and politics. In fact, it contains everything that matters to a man from morning to night. When we talk of Islam, we take it as an all-embracing word. We do not mean any ill will. The foundation of our Islamic code is that we stand for liberty, equality and fraternity." ${ }^{22}$ Qauid considered Islam, the religion of nature and religion of social and political freedom for every man. He did not take Islam a static religion, he believed in the regeneration and revolution in it according to the requirements of the situation. He did not afraid anything except God and advised his people to Allah only as nothing is equal to Him. According to Jinnah's concept, Allah tests those people who are dear to Him. He tested His beloved Prophets and now there were a test from 
God for the Muslims of India whose dear to Him to judge their abilities through Struggle Movement. He said "God often tests and tries those whom He loves. He called upon Prophet Ibrahim to sacrifice the object He loved most. Prophet Ibrahim answered the call and offered to sacrifice his son. Today too, God is testing and trying the Muslims of Pakistan and India." 23

Jinnah considered Western system of economics, the dangerous system for mankind. Western system has not ability to solve the problems of every person on basis of equality and he said that only Islamic system which has a power to solve the problems of mankind in best way. Our progress and prosperity also lies in it. Jinnah pointed out that the financial set-up of the state should be based on Islamic economic system. He explained "The economic system of the west has created almost insoluble problems for humanity and many of us it appears that only a miracle can save it from disaster that is now facing the world. It has failed to do justice between man and man and to eradicate friction from the international field. The adaptation of Western economic theory and practice will not help us in achieving our goal of creating a happy and contented people. We must work our destiny in our own way and present to the world an economic system based justice. We will thereby be fulfilling our mission as Muslims and giving to humanity the message of happiness and prosperity to mankind." 24 Only Islam gave such type of economic system that fulfils the requirements of the peaceful and prosperous country.Western system of economics is very dangerous system which indulge the world into world war 2nd. He praised Islam and advised Muslims that Be truthful and loyal and feel confident that God is always with you.

Jinnah said he worked as a servant of Islam. He performed his duties to save the Muslim interests and created the sense of unity among them. Muslims got Pakistan by the grace of God but now its exciting is more important than creation. Pakistan can maintain its freedom, if people are united otherwise they would lose their freedom. "We are the Muslims and believe in one God, one Book-the Holy Quran-and one Prophet (PBUH). So we must stand united as one nation, you know the old saying that in unity lies strength; united we stand divided we fall." 25 Jinnah wanted to create complete unity among the Muslims for solidarity of Pakistan. He was hopeful about the great task of reconstruction and building up great and glorious Pakistan. He also realized that the solidarity is now more essential at that time than it ever was for achieving Pakistan. No one can be rewarded or anything except Allah. Jinnah talked about sacrifices and hard work for the sacred cause of Pakistan. Jinnah 
thought that the affection and regard that was given by the people to me; depend only for my sincere work for the Muslims and Islam. He said that Muslims were a nation of hundred million people inhabiting this great sub-continent and had a great history and past behind them. Now they should work for the revival and renaissance of Islam and its splendour. "Let us prove worthy of it and bring about true renaissance of Islam and revive its glory and splendour."26

Islam is a universal religion; there is no other religion parallel to it. Our religion is a perfect religion in every aspect. "When we speak about Islam the average Hindus gets alarmed, I have desired that Islam should be free in India. Islam does not mean my faith alone. It means a code for which there is no parallel in the world. It is a complete system of jurisprudence, and social and economic fabric. It has got fundamental principles and has equality, fraternity and liberty as its basic principles." ${ }^{27}$ The power of humbleness is most significant in Islam. Islam believes in practices rather than words. We are convinced that the prayer provide opportunities to men to fulfilling their social instincts. "Man has indeed been called God's caliph in the Quran and if that description of man is to be of any significance it imposes upon us a duty to follow the Quran, to behave towards others as God behaves towards His mankind. In the widest sense of the word, this duty is the duty to love and to forbear." 28 This believed was not a negativity but a positive one. We should honest and sincere in our work. One should adopt the property of tolerance. This will be a service to our country which may not bring into the limelight of politics but it will assure a lasting peace in our hearts in the knowledge that we have contributed our share to making the political task easier.

Islam stresses on the equality of mankind. According to Jinnah's point of view, the main reason of our slavery was caste system. He warned those people who spread this disease. "Islam did not recognize any kind of distinction of various classifications of castes, and the Prophet (PBUH) was able to level down all castes and to create a national unity among Arabs in Arabia. He wanted to destroy the curse of the caste system, which had been the ruin of Muslims of India. "Our bedrock and sheet-anchor is Islam. There is no question even of Shi' $a$ and Sunni. We are one and we must move as one nation and then alone we shall be able to retain Pakistan." ${ }^{29} \mathrm{We}$ became a true and great nation among the world, if we follow the path shown by our Holy Prophet (PBUH). Muslim lost their position, dignity and self respect because they forgot the teachings of Holy Prophet (PBUH). He explained; "We 
must cultivate unity, discipline and faith, and our masses must be educated and organized. Only then can we become a truly great nation and achieve a place of honour amongst the nations of the world. All this we can do and much more, we can achieve, if only we do not go astray the path laid down by the greatest Prophet Muhammad (PBUH). You must remember that we lost our position in the world, because due to some reasons. We could not follow his footstep. ${ }^{30}$ In all these speeches, statements and messages, we see that Jinnah believed on the basic Islamic qualities like patience, loyalty, truth and fear of God. He said that our real protector and well wisher is God, Our destiny in the hands of God. Basic teachings of Islam are equality of mankind, fraternity, fairly, justice and faith. Our salvation depends on these principles.

Quaid considered Quran the basic and perfect source of guidance and inspiration in every walk of life and he was acting according to the injuncture of Holy Quran on all the difficult occasions. He had deep and clear understanding of Quran and his views on constitution, economics, religion, democracy, charity, treatment with minorities and justice were the reflection took from it. He expressed his feelings in his letter to Gandhi in August 1944 "The Quran is complete code of life. It provides for solution of all matters, religious or social, civil or criminal, military or penal, economic or commercial. It regulates every act, speech and movement from the ceremonies of religion to those of daily life, from the salvation of the soul to the health of the body: from the rights of all too each individual, from punishment here the World to come." ${ }^{31}$ Quaid considered Quran the source of guidance for success. He repeated several times in his speeches and statements that principles of Quran and teachings are the solution of our problems and key of our success at any battle. In his message to Muslim Student Federation N.W.F.P. on April 4" 1943, he said; "We have got the greatest message in the Quran for our guidance and enlightenment. All that we have got to do is to know ourselves and the great qualities, Virtues and powers that we possess, let us work up to those great ideas, and let us utilize our great potentialities in the right direction. Let us forgot our personal interests and convenience for the collective good of our people and for a higher and nobler cause." 32 If we follow the great principles of Quran, take inspiration from it and believe it as a great guider then success would be always on the door of ours. He always considered Quran a great book and sheet anchor for the Muslims.

During Pakistan Movement, he pointed out at many occasions that Muhammad (PBUH) should be a role model for every Muslims. We should get inspirations and guidance 
from His (PBUH) life. His address to the lawyers of Karachi on January $25^{\text {th }} 1948$, he said: “ I could not understand a section of the people who deliberately wanted to create mischief and made propaganda that the Constitution of Pakistan would not be make on the basis of shariat.......Islamic principles today are as applicable to life as they were 1300 years ago.....not only $\mathrm{He}(\mathrm{PBUH})$ has reverence of millions but also commands the respect of all the great men of the world." 33 According to Jinnah, salvation of every problem of Muslims of India lays in the practices or followings the footsteps of Holy Prophet's (PBUH) life. Jinnah also said "It is my belief that our salvation lies in following the golden rules of conduct set for us by our great law-giver, the Prophet of Islam. Let us lay the foundation of our democracy based on truly Islamic ideals and principles. Our Almighty has taught us "our decisions in the affairs of the state shall be guide by discussion and consultations". ${ }^{34} \mathrm{Jinnah}$ said we can achieved everything if we follow the footsteps of our Holy Prophet (PBUH). The reasons of our lose was in ignorant the teachings of Prophet (PBUH), "All this we can do and much more can we achieve, if only we do not go astray from the path laid down by the greatest prophet-Muhammad (PBUH). You must remember that we lost our position in the world, because we, for some reason or other, could not follow in his footsteps." 35 Jinnah had a deep love for Prophet (PBUH). He believed Muhammad (PBUH) the great and real sovereign liberator of humanity. He continuously repeated that we cannot succeed until we acted upon the teachings of the Prophet (PBHU).

Jinnah's study about Islam was vast and clear and he sought that foundations of Pakistan should be laid on actual Islamic traditions. If we carefully look at Jinnah's speeches and statements, we can easily understand that he had a moderate approach towards Islam. He provided the combination of modern and traditional thinking and against the religious orthodox personality. According to his ideology, Islam has an elastic approach for different circumstances. Islam gave permission to analyze the facts in logical way. Islam is a rational religion that gave persons permission to observe and think about everything and then accept it. Jinnah's concept of state has close similarity to the Constitution of Medina. This constitution was neither secular in the prevailing sense of the term as the Islamic State of Medina was not a secular state. It recognized the existence of Muslims and Jews as separate entities, though bound together as citizens with mutually agreed obligations and duties. The above mentioned statements are a few out of a large collection of his speeches and statements that clearly indicate Jinnah's perception of Islam. Islam also stresses upon protection of 
human rights, justice and equality before law. He believed and desired that these golden instructions of Islam be taken into practice in Pakistan. Islamic ideas are present almost in every speech of Quaid.

\section{JINNAH'S PERCEPTION OF ISLAM}

Jinnah's perception of Islam has been a matter of interest as well as of dispute. Quaide-Azam was also deep rooted with such type of Modern educated youth who proved himself a good compound of Islamic and Modern values of life. He belonged to a religious family who had deep love for Islam. This is a fact that a man accepts a deep influence from their parental environment, characters and morality. The construction of their dignity of personality also depends upon their family background, parents, environment and educational institutions, so Jinnah got impacts from these Institutions. Jinnah's parents not only had a deep love for religion but also followed the Islamic principles with sincerity. So Jinnah had these qualities. His vision of state basically Islamic but not conform to the thought of traditional Mullahs. His religious political ideas were defined from the life of Holy Prophet (PBUH). To understand his love for Islam, services to Muslims of India and ideological vision of the state of Pakistan, it is necessary to have a closer look at some important aspects of his life and political career. Jinnah's thinking moulded with the passage of time. His thought development can be divided into three phases. His early life, second phase was started from 1920 to 1937 and last phase consist on the period of 1937 to till death.

Quaid's early education was started from Madrsa-tu-Etfal, where he remained up to $4^{\text {th }}$ Standard and later he got admission in first English standard in $4^{\text {th }}$ July $1887^{36}$ in Sindh Madresah-tu-Islam Karachi. At that time mostly missionary's schools were working in India but Muslims wished to send their children in such type of school which were running under the Muslim organizations where their children get Eastern and Western education under the Muslims culture and traditions. Jinnah's study started at home in a religious atmosphere. So he was also fully aware of Muslims norms, traditions and values. Jinnah's character was built on Islamic thoughts and traditions. Love for Islam was streaming in his blood.Jinnah studied the development of law both in England and India. This included both the Muslim and Hindu laws especially the mode of change from the Muslim criminal law to that of the British law the field in which he specialized for his legal practice." ${ }^{37}$ Through the study of different laws, he became able to differentiate the best and worst, true and false, good and bad, beneficial 
and harmful things in life pattern and he became able to fought Muslim case in a best way. He became Barrister and Bar awarded the degree of Bar-at-Law on $29^{\text {th }}$ April $1896 .{ }^{38}$

During his stay in England, he accepted the Western influence and this influence remained almost throughout except last eight years of his life. Although, West influenced on his appearance but he saved his character as a true Muslim. Jinnah started his political career as a liberal Nationalist and a moderate in Indian National Congress in 1906. In the beginning of his political career, he fought for Indians independence without discrimination of Hindus and Muslims. He proved himself as a champion of Indian unity. He tried his best to bring these communities closer but all his efforts shattered on the rock of the intransigence of some of the extremists of the camps. Jinnah was a liberal leader and proud on his title "an ambassador of Hindu-Muslim unity". He spent his early life in struggle for independence of whole India. His political thinking was mainly and mostly Western in its nature in the start of his political career. But later, he transmitted into champion of Muslim identity. There were three groups of Muslims working in India at that time. First, religious movements of Muslims those were orthodox in nature. Second those Ullmas who were the supporters of Congress and third type of people were liberal and modernist, who were fully aware and understand the need of the time. Religious Movements had not been able to know the better politics. CongressiUlemas were Nationalist and totally depended on Congress frame work. Only some people like Sir Syed, AllamaIqbal and Jinnah understood the situation and worked hard for the betterment of the Muslims. Jinnah was fully confident that Muslim League has become the representing organization of the whole Indian Muslims, when some Ullmas were also participated in politics with Muslim League. He requested to the Ullmas to play their role for the benefits of Muslims in politics. With the passage of time, the personality of Jinnah showed different attitude and his political strategy also started to change in twenties to thirties and finally Pakistan Resolution was passed in the forties. In early twenties, Jinnah's only object was to attain a Hindu Muslim settlement, peace and harmony in united India. Later in the thirties and Forties, when all his attempts had failed to create political unity among the Hindus and Muslims, then he realized Hindu mentality and now he devoted himself only for Muslim interests and separate Muslim state. He started to organize them under one flag of Muslim League because he believed that Muslims were one nation, which had one book, one God and one Prophet (PBUH). 
1935-37 was in certain respect the most horrible period that the Muslims of the India ever faced. A marked change can be detected in Jinnah's personality after 1937 and onward. That was the main phase of his life in which his thinking moulded towards Islam and its principles and values. In 1937 election, Congress proved majority in five provinces. Congress formed Ministries in seven Provinces in July 1937. ${ }^{39}$ It is not simple to illustrate it that was one of the darkest periods through which Indian Muslims have had to pass since 1857. That was the starting point of the third phase of Jinnah's thinking. Thesethinking were developed under the Congress attitude towards Muslims during the period of Congress Ministries. Iqbal presented the concept of separate Muslim state in 1930 but Jinnah did not agree with it and ignored this idea but now at that time after the deep thinking of ten years, now Jinnah accepted it. Muslim League demanded the separate Muslim homeland. The change in his thinking would be clearly seen in his speeches and statements which were mostly with the references of Islam and Islamic ideology and his words and concept were clear, simple and precise. He protected the interests of the Muslims because he had concluded that Muslims interests could only be safeguarded in separate Muslim country. Quaid said in this background in December 1938." It is a misfortune of our country, indeed, it is a tragedy that the high command of the Congress is determined, absolutely determined to crush all other communities and cultures in this country and wanted to establish Hindu Raj. After 1937, Jinnah was strongly encouraged and struggled to uplift of the Muslims spirits through practical work and speech after speech at the platform of Muslim League. He also changed his dressing style. He left Western dress and started wearing Muslim dress shalwar, kameez and sherwani for showing the full attachment with the Muslim community .

Sharif ud Din Tussiwas a famous writer, scholar, and educationist of his time. Quaid called him specially and kept him with himself for six months at his house and many English books were written by him. According to the memory of Sharif-ud-Din Tussi that had been translated by his intelligent son Engineer Mr.Haroon-ud-Din Tussi, was published in Friday addition of Naw-e-Waqt episode weekly from May to July in 1988 with topic of "six month with Quaid". In this episodic piece of writing he disclosed some features of politics of that time. He peeped into the life of Quaid-e-Azam. He was impressed by the piousness and religiousness of Quaid. He also made this aspect of Quaid's life a part of history as no one criticized again on this aspect of life. Lots of books had been written by him for Quaid and for this purpose he permitted him to use his personal library. In his library, there were many books about the history of Islam and life of Hazrat Muhammad (PBUH). There were also 
books of some other Islamic scholars and translation books of Quran. Quaid also studied the English translated books, the biography of HazrtUmerFaroq (RA) by ShabliNomani. Quaid studied the English translation of Holy Quran and Syed Ameer Ali's book "The spirit of Islam" which had been translated by Yousf Ali. ${ }^{40}$ Studying of this type of literature, his thoughts converted into complete Islamic way. These changes could be seen not only in his speeches but also in his whole personality. Muslim League wanted to secure the rights of minorities of India, particularly Muslims. He demanded the establishment of free democratic federal government in India. Jinnah's reputation as a Muslim Leader was rising higher to higher. His leadership built his image not only as a powerful and strong leader of the Muslims but also for the minorities.

KokabShadani narrates that he had a craze to meet with Quaid-e-Azam. I expressed my desire when I went to meet with MollanaHasratMohani who was in Dehli at that time. Seeing my crazy wish to meet with Jinnah, he stood up at once. Although the appointment for meeting had not been taken from him, however, Molana went out for meeting due to his courageous behaviour. When they reached at the house of Quaid-e-Azam, there was strict security as usual but they meet with Quaid's secretary. The security guard took us with respect and asked us to be seated in the meeting room. He said to us that although Quaid-eAzam was busy but I informed him about your arrival. Molana replied, no problem! With this, he started to walk here and there in the room but after some time, he went outside. After a short time, I also came out the room in veranda due to confusion. I saw Maulana for peeping into the Quaid's room on his paws. Molana came to guest room hurriedly and then entered in the room. I remained in confusion that what I had to do? Meanwhile the secretary came back and took me with himself. Quaid was also present in the room and MolanaHasrat sahib was sitting in a position like offering prayer. When I put glanced at them, I saw the tears in the eyes of both the leaders. I remained surprised when I questioned Molana sahib about the reason of tears? Molana sahib replied, did you see? When I was peeped into the Quaid's room, I saw that our great leader was offering prayer. I questioned to him surprisingly, who reply? He replied with smile, Array bhae, I am your leader. It was not strange thing that Hazrat was standing on his mat of prayer in his tight dress. The strangest thing was that in spite of his strict behaviour. He was crying before God for a separate home, love for Muslims with undue humbleness and obedience after his prayer. When I saw all this, I entered his room and I took his hands in my hands and we both were crying when he stood 
up from his praying mat. I beg forgiveness for my behaviour from him. your Quaid was very sacred person. ${ }^{41}$ MolanaHasratMohani was a prominent and brave Muslim leader who had a religious personality. Everyone knows his braveness and truthfulness. His narration proved that Jinnah offered his prayers regularly and prayed for the separate Muslims state before God with tears because he had deep affection for his peoples and Islam.

The Jinnah of the 1940 was very different from the Jinnah of 1913-16, or even the Jinnah of the Round Table Conference. There was also a change in his attitude towards the Hindus and to the people in general and their problems. He could perhaps be best compared to a scientist in his laboratory in search of a practical solution to a problem. Many religious associations also worked for Muslims caused at that time. But religious schools of thought did not cooperate and accept Struggle Movement. Indeed they opposed it in the name of Islam. Quaid had to fight on three battles, not only against Hindus and British but also religious orthodox Muslim organizations showed resistance against Pakistan and Jinnah and his point of view about separate Muslim country. But he fought on each battle bravely like a true Muslim.

Malik Habib Ulla informed us in the words of Muhammad Shrif Sahib about Jinnah's figure that there was no contrast or difference between private or personal, public and practical life of Quaid-e- Azam. He got up early in the morning and he used to recite the Holy Quran regularly. There were dozens religious books and journals about the history of Islam in his library. He always remained submissive before his Lord ALLAH and went on his knees before Him, whenever he found himself in any difficulty. He always prayed for guidance and mercy for his peace of mind and soul from ALLAH Almighty. MolanaHsratMohani was witness of his that act and Quaid's submissiveness towards his God. AllmaShabir Ahmad Usmani and his students who knew to be respectful and honourable due to his piousness, agreed for the loving behaviour and caring attitude of Quaid-e-Azam. He said at the last moment of Quaid's funeral that Quaid was a great Muslim after AurangzabAlmigr. ${ }^{42} \mathrm{Sir}$ Owlafcrow remained the Governor of N.W.F.P during 1946 to 1947; he gave him the title of "Mujaddid” in January, 1959 at the event of "Quaid's Day" which was celebrated in London. He said, "Jinnah was much more than a politician, perhaps that is why politicians do not speak well of him. In Muslim terms he was almost a Mujaddid, one of those reformers sent once in a century, as the pious believe, to reinterpret the faith and guide the believers on the true path." 43 Jinnah said on March 23 ${ }^{\text {rd }} 1944$ " for us Pakistan means our defence, our 
deliverance and our destiny. It is the only way in which we can ensure our freedom and the maintenance of our honour." Liberty and freedom is the main pillar of our national Islamic state.

Jinnah said in his letter to Gandhi, "Today you deny that religion can be a main factor in exterminating a nation, but you yourself, when asked what your motive in life ----, the thing that leads us to do what we do, --- was wither it was religious, social or political, said:" Purely religious!". ${ }^{44}$ These letters show that now Jinnah had accepted a Two-Nation theory and considered Muslims a separate nation in place of Nationalism. In another letter to King Ibn Saud, he said "I join you prayer that Almighty may guide our steps in the cause of peace and help us to cement the bonds of Muslims brotherhood and we may stand united on the solid rock of Islam." 45 He considered Islam as a solid rock which united the Muslims of whole world. Quaid's belief and trust on God was very strong, he took great interest in the Holy Quran because his father had given religious education to him. His many friends said that Quaid had been studied the life of Holy prophet (PBUH) very deeply. Whenever Quaid was alone, he recited the Holy Quran and when he found some difficulty in comprehending the verses, he then asked about it from others. He had keen interest in Islam.

Jinnah stands between liberalism and theocracy, the progressive and sectarian, modernist and orthodox. When we keenly read the Quaid's speeches from 1940 to 1947, we come to know that Jinnah stated at least in 90 of them that the state would be an Islamic in spit, which would enforce the shari'ha. Islam demand a fair, justice and responsible attitude free from every kind of bias prejudice and narrow mindedness. After embracing Islam, a person become the member of a new fraternity whose ideological dimensions moral contours and culture boundaries are quite separate from those of any other religion or culture. He has to follow those values which have been prescribed by the Quran and the Sunnah and eschew those which have been prohibited. Jinnah fought the case of Pakistan on ideological bases of Islam. He interpreted Islam and added new dimension to the concepts of nation, democracy and freedom. Mystery of Jinnah's political conversion from Nationalism to Separatism has been discussed by historians and analysts. Jinnah was an ironic and supreme personality. He advocated a separate homeland with gigantic power of pen and mind. He believed that the essential principles of Islam are protection of minorities and equality of rights for women. 
Quaid-i-Azam gave respect toUlema and sought their counselling. He regularly offered prayers after 1943. He also recited the Holy Quran; these traits however found in his early life. Quaid's neighbour and his friends A.B Akram says when it had to be discussing with Quaid-e-Azam about the topic of Islam, we can find that he had good knowledge about Islam. In fact, he was an Islamic scholar. He kept as much knowledge about Islam as no one could beat him in debate about the information of Islam in that time. He had not only studied the Islamic education and information rather he was a practical Muslim and he was proudhimself for being a Muslim. ${ }^{46}$ Jinnah had a strong believe on God. He delivered Presidential address at the special Pakistan session of the Punjab Muslim students Federation Lahore on March 2, 1941. He said, "I am not a learned Maulana or Maulvi. Nor do I claim to be learned in theology. But I know a little of my faith and I am a humble and proud follower of my faith. ${ }^{\circ 47} \mathrm{He}$ did not called himself a Maulvi or Mulah at any stage of his political career to won sympathy of the Muslims during Pakistan Movement for achieving success.

Jinnah copied the Western dress and culture but he was not acted against the basic sprit of Islam. According to his opinion, there was no harm in following the English dress; one should be loyal to Islam in his actions, behaviour and practices. Although his physical appearance was a pure Western man but thinking, actions, character and spirit was totally depend upon the Islamic principles. He was a civilized and honest person. Jinnah buried the concepts of nationalism, patriotism, secularism, unity and integrity after 1937. His main thinking developed from 1937 to 1947 . He forgot the dream of united India and became the destroyer of the unity of the people and of the country. His appetence changed from Western to Eastern style and went ahead for the formation of separate homeland for the preservation of the Islamic religion and culture. He totally left the nationalism and secularism, now he was an Islamist figure who strongly believed on Two-Nation Theory.

\section{CONCLUSION}

Quaid was the most genius personality in the history of Freedom Movement of India. But he had been bitterly criticized by the Hindus and Muslims during his political career. He always expressed his point of view logically and cool-headedly before all. There was no equal and parallel leader to Jinnah in Indian politics. He was against the sectarianism and also advised Muslims that they should not indulge in sectarianism because it was a great schism for national unity and hindrance in the way of success. Islam is not in the favour of 
discrimination between men but lays stress on equality. Jinnah considered that caste system was the main cause for the Muslims to be slave in India, so he advised Muslim to forget it for the unity and success of the country. Jinnah worked for Hindu-Muslim unity. But his each attempt failed and this failure caused so much bitterness and despair. Due to this, he adopted an uncompromising attitude towards the Congress. Now Jinnah's political activities were just for the protection the rights of Muslims, the Islamic heritage and culture in Indian subcontinent. Before 1937, he was a Liberal Nationalist Muslim but after the formation of Congress Government in 1937, he was disappointed because of Hindus behaviour towards Muslims. He sought guidance from Molana Ashraf Ali Thanwi and other Ullmas who encouraged him with their response. He rejected nationalism and became true simple Muslim. He got inspiration from the teachings of the Holy Quran and guidance from the life of Holy Prophet (PBUH). He wanted to lay the foundation of Pakistan on the ground of true ideology of Islam. He tried to induct the spirit of democracy, equality and fraternity in the blood of his nation. But the remaining span of his life was too short to guide newly born nation.

Quaid's last few years were a conscious attempt to move towards Islam in terms of text, purity, and the scripture, and away from modern westernized Islam. He constantly pointed to the principles laid down in the Quran and in the time of the Holy Prophet (PBUH) as the basis of the state. Quran is the basic source of guidance and Jinnah followed the teachings of Quran in his daily life. He often consulted to the Holy Book for seeking guidance for the solution of various issues. Although he had deep sense of Islam because he read Quran with its English translation and Islamic history but he did not consider himself a Moulvi or expert of theology. He got insight from Holy Quran for the solution of Muslim's problem and also followed the teachings of Holy Prophet (PBUH). Quaid believed that Quran covered all aspects of life like social, civil, political, military, judicial and economical. It regulates the whole life of men.

He took Islam as a dynamic and liberal religion. He did not accept it as a static and reactionary force. According to Jinnah's view, Islam allow a new adjustment and fresh experiments to bring change in the society for the best of Muslims and whole mankind. He was impressed and followed the religious thoughts of Sir Syed Ahmad Khan and Syed Amir Ali. He also took guidance from Iqbal's dynamic philosophy. Jinnah advocated Islam as a rational approach. Jinnah freed the minds of Indian Muslims from orthodoxy through his liberalism into traditional Islamic ideas for modern requirements and standards. Jinnah's 
concept of Islam was against both Mullaism and Western secularism in which no there were ethical or spiritual values. He was against the restriction which was adopted by the different rigid religious scholars. He believed that Islam has an elastic approach. He took religion as a universal and social need. If we see Jinnah in holistic approach, it is proved that he was liberal and nationalist in his early age and then he started to turn into religious rationalist after 1937. Jinnah did not take Islam as a static religion. He believed on the regeneration and revolution in it according to the requirements of the situation. In this era, the sect and sectarianism was at the peak particularly in British India. The events of his life show that he was the real follower of the Quran and the Holy Prophet (PBUH). Although Jinnah was Shi'a Muslim by birth but he forcefully called himself a simple Muslim who was not accepted sectarianism in Islam. This study proves that he was a rationalist Muslim. He was brave and straight forward personality who did not compromise at any wrong deed and conversation. He was man of principles. The spirit of Islam that we can see in the life and personality of Jinnah that spirit cannot be found in any Muslim leader in the British India period or after 1947 in Pakistan. 


\section{References}

1- (Ed ),Khurshid Ahmad Khan Yusfi, Speeches, Statements \& Messages of the Quaid-e-Azam,vol iv,p.2604

2- www.lubpak.com, Amir Mir, was Jinnah a secularist? ,p.3,

3 -Muhammad SadiqQusori, Amir-e-MillaturtahrekyPakistan, Majlis e jamet e Pakistan, p.65-69

4- Ibid....,p.3

${ }^{5}$-www.lubpak.com/archives, Amir Mir, was Jinnah a secularist? ,p.3

6. Ibid, p.4

7. Justice Munier, from Jinnah to Zia, Lahore, 1979, p. vii

8 - Saad R. Khairi, Jinnah reinterpreted: the journey to nationalism to Muslim statehood, Karachi, 1995,pp. vi$\mathrm{xx}$

9 - Z.A Suleri, My leader,Rawalpindi, 1992, p.37-55

10 - All Pakistan Leagual Decisions 1970, High Court of Sindh, Karachi, no. 450, Miscellaneous Application No. 11/1968, ruled 2 March 1970.

11 :- Dr AjeetJaweed, Secular and Nationalist Jinnah,Karachi,2009,p.13

12- StanelyWalport, Jinnah of Pakistan, p. 53

${ }^{13}$-Aqeel Abbas Jaferi, Quaid-e-AzamkeAzdwajiZindgi, Lahore, 1995,p.47-48

14- StanelyWalport, Jinnah of Pakistan, p. 370

15 - Liaqut H. Merchant, Sharif-ul-Mujahid (Ed), Jinnah anthology, oxford, New York, 1999.

16. Professor Zia-ud-din Ahmad, Mohmmad Ali Jinnah :the Archeticture of Pakistan, Karachi,2000,p. 146

17 - see for detail Khalid Ahmad, Sectarian War,Karachi,2011, p.8

18 (Ed) Muhammad HanifShahid, Tribute to Quaid-e-Azam, Lahore, 1976, pp 207-08

19 - (Ed)Khurshid Ahmad Khan Yousfi, Speeches Statements \& Messages of the Quaid-e-Azam, V 4,P. 2258

20. Ibid, V 4,P. 2633

21 - (Ed)Khurshid Ahmad Khan Yousifi, Speeches Statements \& Messages of the Quaid-e-Azam, Lahore, vol. iv, 1996, p. 2670

22-Khurshid Ahmad Khan Yousifi (ed), Speeches statements \& Messages of the Quaid-e-Azam, p. 692

23- ibid.,vol iv, p. 2629

24- (Ed) Khurshid Ahmad Khan Yousifi, Speeches statements \& Messages of the Quaid-e-Azam,vol iv, p. 2787

25 - Ibid, vol vi, p. 2759

26- Ibid, vol iii,p. 1766

27- Ibid ,vol ii, p. 719

${ }^{28}$-Ibidvol ii, p 1060-63

${ }^{29}$-(Ed) Khurshid Ahmad Khan Yousifi, Speeches statements \& Messages of the Quaid-e-Azam, vol iii, p 1859

30 - (Ed)Khurshid Ahmad Khan Yousifi, Speeches Statements \& Messages of the Quaid-e-Azam, p. 2519-20

31 - Z.H. Zaidi, Jinnah papers, vol xi, Lahore, published date not found.

32. (Ed) Khurshid Ahmad Khan Yousifi, Speeches Statements \& Messages of the Quaid-e-Azam, vol iii, p. 1687

33- Ibid,vol iv, p. 2669-70

34- Ibid, p. 2682

35 - Ibid, p. 2520

36- Rizwan Ahmad, Quaid-i-AzamkezindgikayIbatada-e-Tees Saal, p. 57

37- DrRiaz Ahmad, Jinnah's conception of Islam and Pakistan , p. 4-5

38 - Ibid, p. 6

39. Pro Zia-u-Din Ahmad, The architecture of Pakistan, Karachi, 2000, p. 72

40. Malik Habibullah, Quaid-e-Azamkeshakhseyatkarohanipehl(Urdu), Lahore, 1998,p.29-34

41. KokabShdani, MahNamaNazrya, Quaid-e-Azamkuchyadaenkuchbaten, shumara 4,Islambabad, April, 2012.

42. Malik Habibullah, Quaid-e-Azamkeshakhseyatkarohanipehlo (Urdu), Lahore, 1998,p.6-7

43 - (Ed) Jamil-ud-Ahmad, Quaid as seen by his contemporaries,Lahore,1956, p.228

44 - Z.H.Zidi, Jinnah papers, volum xv, p 76, leter no 49

45 - Ibid, , leter no 68, vol. 2,p. 138

47- (Ed) Khurshid Ahmad Khan Yousifi, Speeches Statements \& Messages of the Quaid-e-Azam, V 2,p .1334 